\title{
A PRELIMINARY STUDY ON UTILIZATION OF DIFFERENT HENNA EXTRACTS COMPARED WITH IBA ON ROOTAPILITY OF DOGRIDGE GRAPE ROOTSTOCK CUTTINGS
}

\author{
HAMOUDA A. M. A. ${ }^{1}$ and GEHAN H. SABRY ${ }^{2}$ \\ 1. Medicinal \& Aromatic plant Research Dept. Hort. Res. Inst., ARC, Giza \\ 2. Viticulture Research Dept., Hort. Res. Institute, ARC, Giza
}

(Manuscript received 12 July 2012)

\begin{abstract}
The present work was carried out during the two successive seasons of 2010 and 2011 in the shade house of the Viticulture Department, Horticulture Research Institute, in Giza, Agric. Res. Center, Ministry of Agriculture. The used cuttings were taken from mother Dogridge vines grown in the private farm at $58 \mathrm{Km}$ Cairo Alex. desert road. Hard-wood cuttings were taken in Jan. from moderately vigorous 1-year-old canes, each cutting comprised three nodes (eyes) and was about 30-35 cm long. The cuttings were stored with their basis upwards in the shade house until planting on $15 \mathrm{Feb}$. in both seasons Henna extracts obtained from the crushed dried leaves of Lawsonia inermis L. $200 \mathrm{gm}$ Henna was immerged in one liter for 48 hours in one of the following solvents:tap water, boiled water, ethyl alcohol, hexane, acetone and petroleum ether. The used concentration from henna crude extracts by different solvents was $3 \mathrm{gm} / \mathrm{I}$ of distilled water (i.e. 3000 $\mathrm{ppm}$ ). Cuttings were soaked in each of the considered extracts for 24 hours before planting. In addition, the recommended application of the growth regulator IBA at $(1000 \mathrm{ppm})$ by dipping for 10 seconds was used as a control. The best results were obtained by henna extracted by acetone and tap water solvent without significant differences among them. While, untreated cuttings gave the lowest results followed by cuttings treated by ethyl alcohol extract and than IBA treatment. The other henna extractions were ranged between them. Generally, it is possible to improve rootapility of Dogridge grape rootstock cuttings by soaking cutting basis in henna extracted by acetone or tap water solvents which gave nearly similar effect, but use of tap water solvent, is more economic and easier for application.
\end{abstract}

\section{INTRODUCTION}

Many higher plants produce economically important organic compounds such as oils, resins, tannins, natural rubber, gums, waxes, dyes, flavors and fragrances, pharmaceuticals, promoters, inhibitors and pesticides. However, most species of higher plants have never been described, much less surveyed for chemical or biologically active constituents, and new sources of commercially valuable materials remain to be discovered. Advances in biotechnology, particularly methods for culturing plant cells and tissues, should provide new means for the commercial processing of 
even rare plants and the chemicals they produce. These new technologies will extend and enhance the usefulness of plants as renewable resources of valuable chemicals. In the future, biologically active plant-derived chemicals can be expected to play an increasingly significant role in the commercial development of new products for regulating plant growth and for insect and weed control.

Henna, a natural product obtained from the crushed leaves of Lawsonia inermis $\mathrm{L}$. has been used for many centuries as a cosmetic agent to dye the skin, hair, and nails of people in many Middle Easte countries, and large amounts of it are imported for this purpose into the United States. Application of henna has resulted in life-threatening episodes of hemolytic anemia, particularly in individuals with a genetic deficiency in erythrocytic glucose-6-phosphate dehydrogenase (G6PD) activity (Raupp et. al., 2001, Zinkham and Oski, 1996). The active dye ingredient, lawsone (2hydroxy-1,4-naphthoquinone), which constitutes about $1 \%$ of the dry weight of the leaves, has been implicated in the causation of henna-induced hemolytic anemia because of its structural similarity to other ortho-substituted 1,4-naphthoquinones, such as menadione (2-methyl-1,4-naphthoquinone), that are known to induce oxidative injury within red cells. 1,4-Naphthoquinones are thought to induce oxidative damage as a consequence of their ability to undergo redox cycling with the generation of reactive oxygen species (ROS) (Munday et. al., 1994). In support of this concept, oxidative responses to in vitro exposure of red cells to menadione (i.e., hydrogen peroxide formation, GSH depletion, methemoglobin production, and the presence of Heinz bodies) have been shown to correlate with hemolytic activity in vivo (Munday et. al., 1991).

The constituents of Henna is found in it in a brown substance of a resinoid fracture, having the chemical properties which characterize the tannins, and therefore named hennotannic acid. Dried, powdered leaves of henna contain about 0.5 to 1.5 percent lawsone, the chief constituent responsible for the dyeing properties of the plant. Henna also contains mannite, tannic acid, 2-hydroxy-1:4-naphthoquinone resin mucilage, gallic acid, glucose, mannitol,fat, resin and mucilage are also present. The colorings matter is the quinone .and napthaquinone.

The nematode-resistant grape rootstock "Dogridge," is variety of the American wild species Vitis champini. Dogridge is extremely resistant to nematodes and moderately resistant to phylloxera. It is recommended for the lighter, less fertile sandy soils (Winkler et al. 1974). According to Sauer (1977) Vitis champini varieties Ramsey and Dogridge were the rootstocks with best resistance to the root-knot nematode Meloidogyne javanica under Australian conditions. The two rootstocks are difficult-to-root plants. 
Therefore, the present study was outlined to enhance rootapility of Dogridge cuttings through some henna extracts treatments compared to the best IBA treatment for rooting of Dogridge rootstock cuttings (1000 ppm) Sabry, Gehan (2004).

\section{MATERIALS AND METHODS}

The present work was carried out during the two successive seasons of 2010 and 2011 in the shade house of the Viticulture Department, Horticulture Research Institute, in Giza, Agric. Res. Center, Ministry of Agriculture. The used cuttings were taken from mother Dogridge vines grown in the private farm at $58 \mathrm{Km}$ Cairo - Alex. desert road.

Hard-wood cutting were taken in Jan. from moderately vigorous 1-year-old canes, each cutting comprised three nodes (eyes) and was about $30-35 \mathrm{~cm}$ long. The cuttings were stored with their basis upwards in the shade house until planting on 15 Feb. in both seasons

Henna extracts obtained from the crushed dried leaves of Lawsonia inermis $\mathrm{L}$. $200 \mathrm{gm}$ Henna was immerged in one liter for 48 hours in one of the following solvents:- tap water, boiled water, ethyl alcohol, hexane, acetone and petroleum ether.

The henna extracts by different solvents were evaporated by rotary evaporator under reduced pressure below $60^{\circ} \mathrm{C}$ and were then dried in vacuo below $40^{\circ} \mathrm{C}$ and weighed to determine the yield of crude extract percentage and total analysis of henna crude extracts according to Pharmacognosy Department, Fac. of Pharmacy . Cairo Univ..

The used concentration from henna crude extracts by different solvents was $3 \mathrm{gm} /$ I of distilled water (i.e.3000 ppm). Cuttings were socked in each of the considered extracts for 24 hours before planting. In addition, the traditional application of the growth regulator IBA at (1000 ppm) by dipping for 10 seconds was used as a control Gehan Sabry, Gehan (2004). The treatments were as follows:-

1- Untreated cutting (control).

2- Cutting bases were dipped for $10 \mathrm{sec}$. in (IBA) solutions at (1000 ppm recommended dose).

3- Cutting bases were socked in henna extracted by tap water for 24 hours.

4- Cutting bases were socked in henna extracted by boiled water for 24 hours.

5- Cutting bases were socked in henna extracted by ethyl alcohol for 24 hours.

6- Cutting bases were socked in henna extracted by hexane for 24 hours.

7- Cutting bases were socked in henna extracted by acetone for 24 hours.

8- Cutting bases were socked in henna extracted by petroleum ether for 24 hours. 
Each treatments comprised 60 cuttings. Cuttings were planted in plastic bags containing a mixture of peatmoss and sand $(1: 2 \mathrm{~V} / \mathrm{V})$. Cuttings shared between three replicates, each replicate contains 20 cuttings.

The effects of tested treatments were evaluated through the following parameters:

\section{Morphological and chemical studies}

Cutting of all treatments were kept in the plastic bags for 9 months. Budburst was recorded after three weeks until six weeks from planting. Samples of 3 cuttings each replicate were taken at the first and second months and at the end of experiment (after 9 months from planting) to determine the number of roots and total lengths of roots/cutting. In addition, bud samples were detached to determine endogenous hormones, (promoters and inhibitors contents).

After planting, the growing cuttings remained in the shade house until the end of the season ( 9 months after planting). After removing culture medium, the number of roots/plant, average length of roots/plant, number of leaves/plant, as well as fresh weights of root system were recorded.

\section{Endogenous bud hormones determinations}

Three grams of frozen buds were ground in cold aqueous methanol (80 V:V) using a mortar and pestle. The macerate was transferred to a flask with fresh methanol and the volume was adjusted to $20 \mathrm{ml}$ of methanol for each $\mathrm{g}$ fresh weight. The tissue was allowed to extract for 24 hours at $0^{\circ} \mathrm{C}$ and then was vacuum filtered through Whatman paper No. 42. The filter paper and the residue were returned to the flask with a fresh volume of methanol, shaken for $30 \mathrm{~min}$. on a wrist action shaker and filtered again. The procedure was repeated once more and the combined extracts were evaporated to the aqueous phase in a rotary flask evaporator. The aqueous phase $(10$ to $30 \mathrm{ml}$ ) was adjusted to $\mathrm{pH} 8.6$ with $1 \% \mathrm{NaOH}$ and partitioned three times with equal volumes of ethyl acetate. The combined ethyl acetate fraction was evaporated to dryness and held for further purification. The aqueous phase was adjusted to $\mathrm{pH} 2.8$ with $1 \% \mathrm{HCl}$ and partitioned three times with equal volumes of ethyl acetate. The remaining aqueous phase was discarded. The combined acidic ethyl acetate phase was reduced in volume to be used for G.L.C determination of acidic hormones IAA, ABA and GA (Wasfy, 1975).

The obtained data were statistically analyzed using the randomized block design with three replicates. The obtained data were subjected to statistical analysis of variance according to Snedecor and Cochran (1980) and means separation was done according to New LSD at the $5 \%$ level. 


\section{RESULTS AND DISCUSSION}

Efficiency of different solvents on productivity of crude extracts from henna crushed leaves

Data in Taple (1) and Fig (1) show that, the productivity of crude extracts of henna extracts by different solvents after being evaporated by a rotary evaporator system. The solvent effect was very clear. Generally, the crude extracts was low 4.1 gm ( $2.05 \%)$ for henna extracted by hexane then its gradually increased to $22.1 \mathrm{gm}$ (11.05\%) for henna extracted by acetone, $48.1 \mathrm{gm}$ (24.05\%) for henna extracted by ethyl alcohol, $67.5 \mathrm{gm}$ (33.75\%) for henna extracted by petroleum ether, $67.7 \mathrm{gm}$ $(33.85 \%)$ for henna extracted by tap water and $71.6 \mathrm{gm}$ (35.8 \%) for henna extracted by boiled water.

Taple 1. The crude extract production from henna extracts by different solvents after being evaporated by a rotary evaporator system.

\begin{tabular}{|c|c|c|c|}
\hline Solvents & $\begin{array}{c}\text { Henna dry } \\
\text { leaves(gm) }\end{array}$ & $\begin{array}{c}\text { Weight of henna crude } \\
\text { extract (gm) }\end{array}$ & $\begin{array}{c}\text { Crude extract } \\
\%\end{array}$ \\
\hline Tap water & 200 & 67.7 & 33.85 \\
\hline Boiled water & 200 & 71.6 & 35.8 \\
\hline Acetone & 200 & 22.1 & 11.05 \\
\hline Hexane & 200 & 4.1 & 2.05 \\
\hline Petroleum ether & 200 & 67.5 & 24.75 \\
\hline Ethyl alcohol & 200 & 48.1 & \\
\hline
\end{tabular}

\section{Budburst percentage}

Data in Taple (2) show the effect of some henna extracts by different solvents, all at (3000 ppm) compared to IBA (1000 ppm) and untreated cuttings on budburst (\%) on Dogridge stem cuttings 3, 4, 5 and 6 weeks after planting in 2010 and 2011 seasons. 
Taple 2. Effect of different henna extracts compared with IBA on budburst percentage of Dogridge grape rootstock cuttings during two seasons (2010\&2011) .

\begin{tabular}{|c|c|c|c|c|}
\hline \multirow[b]{2}{*}{ Treatments } & \multicolumn{4}{|c|}{ Budburst percentage (\%) } \\
\hline & $\begin{array}{c}\text { After } 3 \\
\text { weeks from } \\
\text { planting }\end{array}$ & $\begin{array}{c}\text { After } 4 \\
\text { weeks from } \\
\text { planting }\end{array}$ & $\begin{array}{c}\text { After } 5 \\
\text { weeks from } \\
\text { planting }\end{array}$ & $\begin{array}{c}\text { After } 6 \\
\text { weeks from } \\
\text { planting }\end{array}$ \\
\hline \multicolumn{5}{|c|}{ First season 2010} \\
\hline Untreated cutting & 0.0 & 28.9 & 33.4 & 46.7 \\
\hline IBA (1000 ppm) & 13.3 & 28.9 & 40.0 & 51.1 \\
\hline Henna extracted by tap water & 13.3 & 46.7 & 62.2 & 64.5 \\
\hline Henna extracted by boiled water & 13.3 & 26.7 & 35.6 & 53.3 \\
\hline Henna extracted by acetone & 4.4 & 20.0 & 42.2 & 68.9 \\
\hline Henna extracted by hexane & 8.9 & 28.9 & 42.2 & 51.1 \\
\hline Henna extracted by petroleum ether & 2.2 & 26.7 & 66.7 & 68.9 \\
\hline Henna extracted by ethyl alcohol & 6.7 & 17.8 & 40.0 & 62.2 \\
\hline New L.S.D. at 5\% & 9.8 & 17.8 & 11.58 & 9.6 \\
\hline \multicolumn{5}{|c|}{ Second season 2011} \\
\hline Untreated cutting & 3.2 & 15.6 & 31.1 & 46.7 \\
\hline IBA (1000 ppm) & 4.4 & 35.5 & 44.4 & 48.9 \\
\hline Henna extracted by tap water & 26.6 & 46.7 & 55.6 & 66.7 \\
\hline Henna extracted by boiled water & 8.9 & 31.1 & 53.3 & 64.4 \\
\hline Henna extracted by acetone & 6.7 & 44.5 & 57.8 & 71.1 \\
\hline Henna extracted by hexane & 6.7 & 28.9 & 55.6 & 62.2 \\
\hline Henna extracted by petroleum ether & 4.4 & 20.0 & 44.4 & 64.4 \\
\hline Henna extracted by ethyl alcohol & 2.2 & 15.6 & 26.7 & 60.0 \\
\hline New L.S.D. at 5\% & 8.13 & 15.24 & 16.09 & 14.39 \\
\hline
\end{tabular}

The data, generally, show that, budburst (\%) ranged $0.0-13.3 \%$ and $2.2-$ $26.6 \%$ at 3 weeks, $17.8-46.7 \& 15.6-46.7 \%$ at 4 weeks, $33.4-66.7 \& 26.7-$ $57.8 \%$ at 5 weeks and $46.7-68.9 \& 46.7-71.1 \%$ at 6 weeks after planting in the $1^{\text {st }} \& 2^{\text {nd }}$ seasons, respectively. Regarding the effect of different henna extracts, it was significant in all counting weeks in the two seasons. Budburst gradually increased with the advance in season after planting. In addition, the least values were always recorded for the control followed by henna extracted by ethyl alcohol, while the uppermost values were recorded by henna extracted by acetone and henna extracted by tap water which gave the highest budburst (\%) values compared with other treatments, the differences between them were always significant. Values of other treatments were always in between. 


\section{Number of roots/cutting}

Taple (3) and photo (1) illustrate the effect of tested henna extracts by different solvents compared to IBA (1000 ppm) and untreated cuttings on number of roots/cutting of Dogridge rootstock. The roots were counted at 2, 4 and 9 months (at the end experiments) after planting in 2010 \& 2011.

Taple 3. Effect of different henna extracts compared with IBA on root number of Dogridge grape rootstock cuttings during two seasons (2010\&2011) .

\begin{tabular}{|c|c|c|c|}
\hline \multirow[b]{2}{*}{ Treatments } & \multicolumn{3}{|c|}{ Roots number per cutting } \\
\hline & $\begin{array}{c}\text { After two } \\
\text { months from } \\
\text { planting }\end{array}$ & $\begin{array}{c}\text { After four } \\
\text { months from } \\
\text { planting }\end{array}$ & $\begin{array}{l}\text { After } 9 \text { months } \\
\text { (at the end of } \\
\text { experiment) }\end{array}$ \\
\hline \multicolumn{4}{|c|}{ First season } \\
\hline Untreated cutting & 0.0 & 17.7 & 20.0 \\
\hline IBA (1000 ppm) & 4.3 & 27.0 & 31.3 \\
\hline Henna extracted by tap water & 36.0 & 38.7 & 40.0 \\
\hline Henna extracted by boiled water & 26.0 & 26.3 & 30.3 \\
\hline Henna extracted by acetone & 41.3 & 42.0 & 43.0 \\
\hline Henna extracted by hexane & 14.3 & 26.3 & 27.3 \\
\hline Henna extracted by petroleum ether & 16.0 & 24.3 & 26.0 \\
\hline Henna extracted by ethyl alcohol & 4.7 & 18.3 & 22.7 \\
\hline New L.S.D. at 5\% & 9.25 & 7.67 & 6.36 \\
\hline \multicolumn{4}{|c|}{ Second season } \\
\hline Untreated cutting & 0.0 & 19.0 & 21.0 \\
\hline IBA $(1000 \mathrm{ppm})$ & 9.3 & 28.0 & 29.3 \\
\hline Henna extracted by tap water & 34.0 & 35.7 & 39.0 \\
\hline Henna extracted by boiled water & 19.0 & 28.7 & 32.0 \\
\hline Henna extracted by acetone & 35.0 & 35.0 & 37.3 \\
\hline Henna extracted by hexane & 35.3 & 36.0 & 39.3 \\
\hline Henna extracted by petroleum ether & 12.0 & 21.3 & 24.7 \\
\hline Henna extracted by ethyl alcohol & 7.3 & 20.0 & 23.3 \\
\hline New L.S.D. at 5\% & 7.15 & 4.04 & 3.18 \\
\hline
\end{tabular}

It was also generally observed that number of roots/ cutting was gradually increased with the advance in season.

In both seasons, the effect of henna extracts was obvious. The greatest root numbers were obtained by henna extracted by acetone ( $41.3 \& 35.0$ after 2 months), (42.0 \& 35.0 after 4 months) and (43.0 \& 37.3 after 9 months) and henna extracted by tap water (36.0 \& 34.0 after 2 months), (38.7 \& 35.7 after 4 months) and (40.0 \& 39.0 after 9 months) in the two seasons respectively, without significant differences between them in each season. 
The values ranged $0.0-41.3 \& 0.0-35.3$ after two months, $17.7-42.0 \&$ $19.0-35.7$ at four months and $22.7-43.0 \& 21.0-39.3$ at nine months after planting in the two seasons respectively. The least root number were obtained from untreated cutting in the two seasons as ascendingly followed by IBA (1000 ppm) and ethyl alcohol henna extract. The other treatments were gave in between root numbers.

\section{Average of roots length / cutting}

Data in Table (4) and photo (1) illustrate, the effect of different henna extracts under study compared to IBA (1000 ppm) and untreated cuttings on average roots length /cutting of Dogridge rootstock. The roots length were measured at 2, 4 and 9 months (at the end of experiment) after planting in 2010 \& 2011.

Taple 4. Effect of different henna extracts compared with IBA on average of root length $(\mathrm{cm})$ of Dogridge grape rootstock cuttings during two seasons (2010\&2011).

\begin{tabular}{|c|c|c|c|}
\hline \multirow[b]{2}{*}{ Treatments } & \multicolumn{3}{|c|}{ Average of root length $(\mathrm{cm})$} \\
\hline & $\begin{array}{c}\text { After two } \\
\text { months from } \\
\text { planting }\end{array}$ & $\begin{array}{c}\text { After four } \\
\text { months from } \\
\text { planting }\end{array}$ & $\begin{array}{l}\text { After } 9 \text { months } \\
\text { from planting } \\
\text { (at the end of } \\
\text { experiment) }\end{array}$ \\
\hline \multicolumn{4}{|c|}{ First season } \\
\hline Untreated cutting & 0.0 & 4.1 & 20.3 \\
\hline IBA (1000 ppm) & 2.6 & 12.8 & 28.5 \\
\hline Henna extracted by tap water & 4.0 & 14.5 & 33.0 \\
\hline Henna extracted by boiled water & 2.7 & 6.6 & 27.8 \\
\hline Henna extracted by acetone & 4.5 & 17.9 & 47.0 \\
\hline Henna extracted by hexane & 3.3 & 13.5 & 30.3 \\
\hline Henna extracted by petroleum ether & 2.3 & 12.0 & 29.7 \\
\hline Henna extracted by ethyl alcohol & 1.0 & 9.3 & 27.7 \\
\hline New L.S.D. at 5\% & 1.25 & 4.32 & 9.04 \\
\hline \multicolumn{4}{|c|}{ Second season } \\
\hline Untreated cutting & 0.0 & 2.9 & 20.3 \\
\hline IBA $(1000 \mathrm{ppm})$ & 1.5 & 13.4 & 31.5 \\
\hline Henna extracted by tap water & 4.1 & 14.5 & 35.7 \\
\hline Henna extracted by boiled water & 1.7 & 9.0 & 19.7 \\
\hline Henna extracted by acetone & 4.2 & 15.3 & 38.5 \\
\hline Henna extracted by hexane & 3.2 & 13.6 & 34.3 \\
\hline Henna extracted by petroleum ether & 2.6 & 12.5 & 27.7 \\
\hline Henna extracted by ethyl alcohol & 0.9 & 9.4 & 29.7 \\
\hline New L.S.D. at 5\% & 1.32 & 1.96 & 5.07 \\
\hline
\end{tabular}

The average root length, generally, ranged $0.0-4.5 \& 0.0-4.2 \mathrm{~cm}$ after 2 months, $4.1-17.9 \& 2.9-15.3 \mathrm{~cm}$ after 4 months and $20.3-47.0 \& 20.338 .5 \mathrm{~cm}$ after 9 months from planting in the first and second seasons, respectively. 
In both seasons, the effect of henna extracts by different solvents was most clear with henna extracted by acetone solvent which gave the longest root length by the end of experiment after 9 months $(47.0 \& 38.5 \mathrm{~cm})$, closely followed by henna extracted by tap water solvent $(33.0 \& 35.7 \mathrm{~cm})$ the same trend was observed in the former sampling dates. However some tested extracts gave statistical similar effect at same of the monitoring dates in one of the two experimental seasons. The least root length always were obtained by untreated cuttings, also henna extracted by alcohol solvent gave lowest root length between all henna extracts and IBA treatments.

Generally it is obvious that all henna extracts promoted root formation on cuttings of Dogridge rootstock by different solvents in addition to IBA treatment (1000 ppm).

Photo 1. Effect of different henna extracts compared with IBA on rootapility of Dogridge grape rootstock after two months from planting.
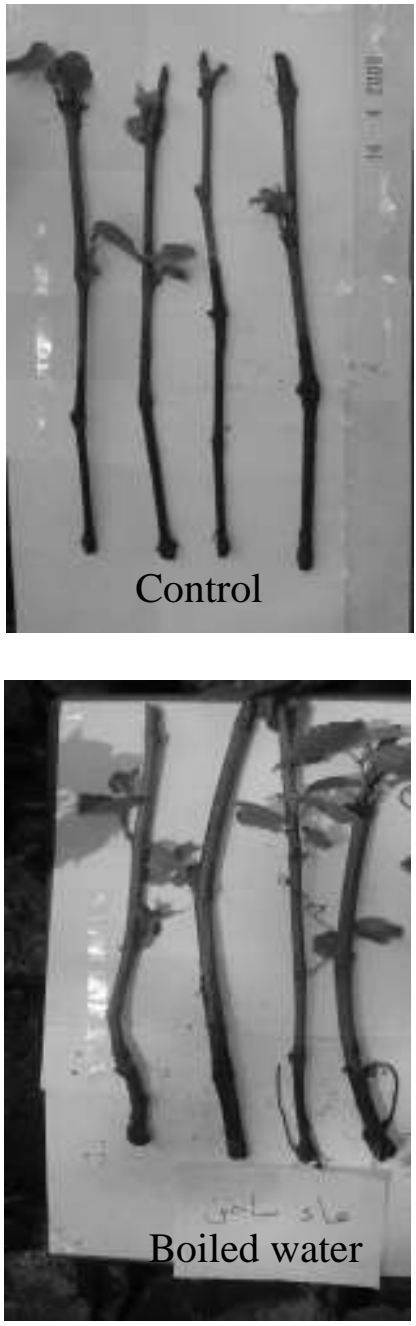
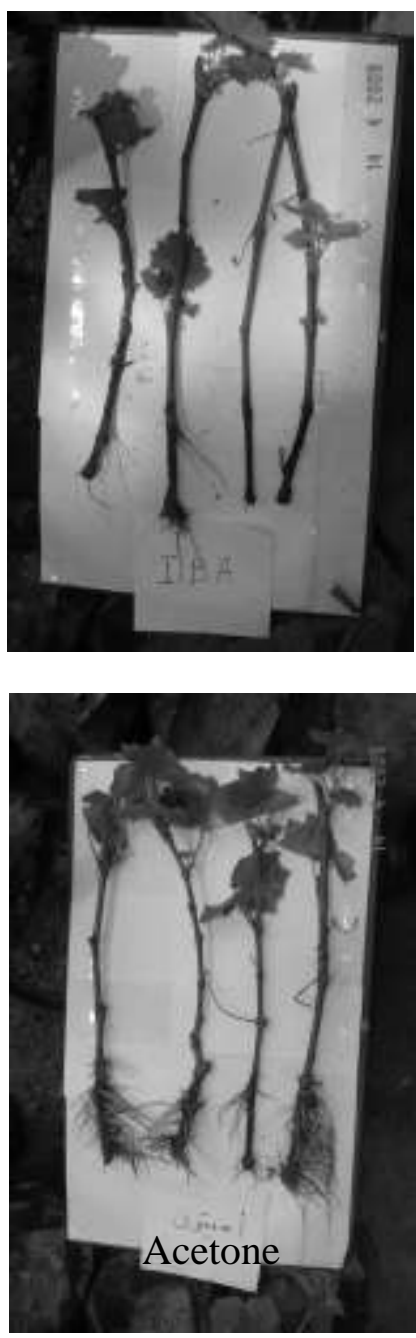
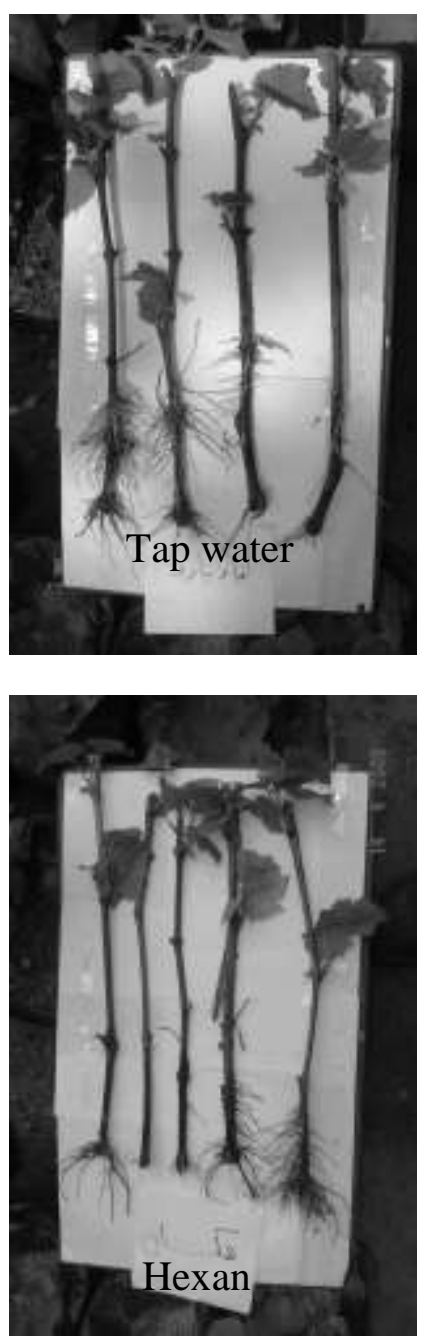
Photo 1. continued
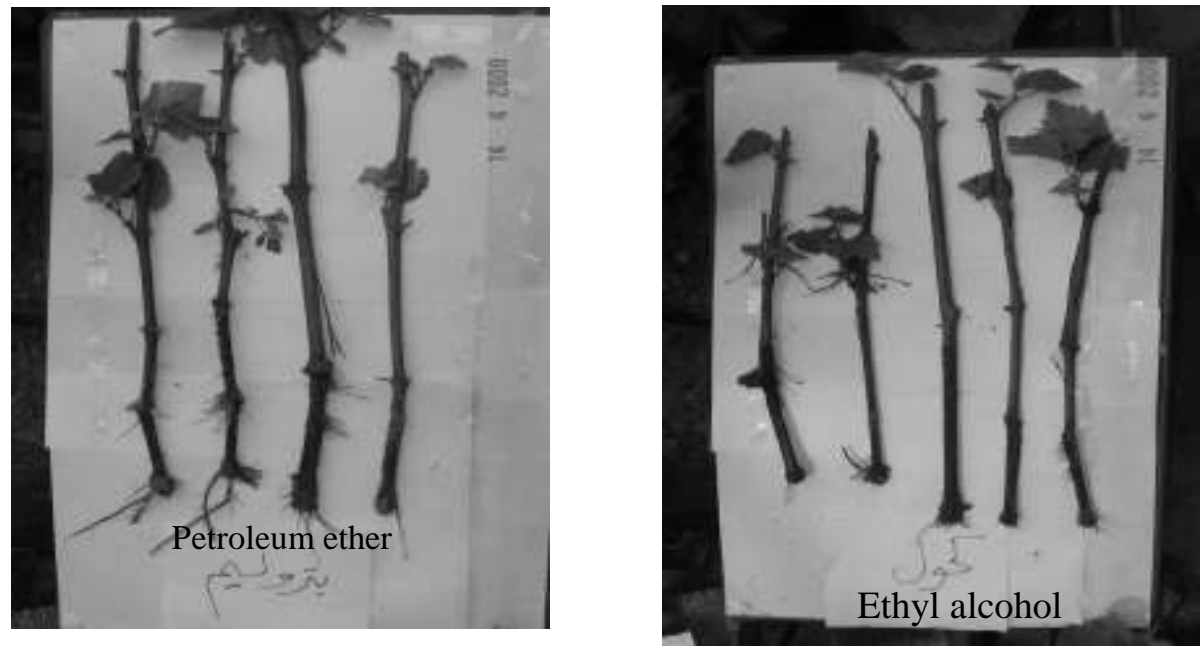

\section{Growth vigor and survival percentage}

Taple (5) clarify the effect of some henna extracts by different solvents compared to IBA (1000 ppm) and untreated cuttings on survival percentage of Dogridge rootstock cuttings in the two seasons investigation (2010 \& 2011).

The effect of henna extracts by different solvents was significant with all considered parameters in the two seasons. The best results were obtained by henna extracted by acetone solvent which recorded the highest values followed by henna extracted by tap water and henna extracted by hexane solvent with most of the considered parameters in the two seasons. However, some other tested henna extracts gave statically similar effect. The values were ranged from (22.0 to $27.0 \mathrm{~cm}$ ) \& ( 21.3 to $25.5 \mathrm{~cm}$ ) for plant height, ( 7.7 to 22.0 ) \& (8.0 to 27.0 ) for leaves number, (21.7 to $67.0 \mathrm{gm}$ ) \& (18.7 to $61.7 \mathrm{gm}$ ) for fresh weight of root system and (60 to 96.7 $\%) \&(60$ to $93.3 \%$ ) for survival percentage at the end of each seasons.

The untreated cuttings gave the lowest values in all parameters in the two seasons. IBA (1000 ppm) gave values lower than all henna extracts by different solvents except henna extracted by alcohol solvent which gave values lower than IBA treatment especially at the first season.

Generally, the obtained results reveled that henna extracted by acetone solvent flowed by henna extracted by tap water solvent were the best extracts for budburst, rooting, growth vigor and survival of Dogridge rootstock cuttings. 
Taple 5. Effect of different henna extracts compared with IBA on plant height $(\mathrm{cm})$, leaves number, fresh weight of root system ( $\mathrm{gm}$ ) and survival percentage of Dogridge grape rootstock cuttings at the end of the two seasons (2010\&2011).

\begin{tabular}{|c|c|c|c|c|}
\hline \multirow[t]{2}{*}{ Treatments } & \multicolumn{4}{|c|}{ At the end of experiment ( 9 months) } \\
\hline & $\begin{array}{c}\text { Plant } \\
\text { height }(\mathbf{c m})\end{array}$ & $\begin{array}{c}\text { Leaves } \\
\text { number/ } \\
\text { Plant }\end{array}$ & $\begin{array}{c}\text { F.W. of root } \\
\text { system/pla } \\
\text { nt(gm) }\end{array}$ & $\begin{array}{l}\text { Survival } \\
\text { percentage }\end{array}$ \\
\hline \multicolumn{5}{|c|}{ First season } \\
\hline Untreated cutting & 22.0 & 7.7 & 21.7 & 60.0 \\
\hline IBA (1000 ppm) & 24.3 & 14.0 & 31.7 & 70.0 \\
\hline Henna extracted by tap water & 25.3 & 17.7 & 45.0 & 96.7 \\
\hline Henna extracted by boiled water & 23.3 & 17.7 & 31.7 & 86.7 \\
\hline Henna extracted by acetone & 27.0 & 22.0 & 67.0 & 96.7 \\
\hline Henna extracted by hexane & 26.7 & 16.7 & 53.3 & 83.3 \\
\hline $\begin{array}{c}\text { Henna extracted by petroleum } \\
\text { ether }\end{array}$ & 24.5 & 11.7 & 31.7 & 93.3 \\
\hline Henna extracted by ethyl alcohol & 22.2 & 9.3 & 24.3 & 80.0 \\
\hline New L.S.D. at 5\% & 3.44 & 8.52 & 5.91 & 8.31 \\
\hline \multicolumn{5}{|c|}{ Second season } \\
\hline Untreated cutting & 21.3 & 8.0 & 18.7 & 60.0 \\
\hline IBA (1000 ppm) & 23.7 & 13.7 & 30.0 & 73.3 \\
\hline Henna extracted by tap water & 25.3 & 15.7 & 35.0 & 86.7 \\
\hline Henna extracted by boiled water & 22.7 & 13.0 & 30.0 & 83.3 \\
\hline Henna extracted by acetone & 25.5 & 27.0 & 61.7 & 93.3 \\
\hline Henna extracted by hexane & 25.2 & 16.3 & 46.7 & 83.3 \\
\hline $\begin{array}{c}\text { Henna extracted by petroleum } \\
\text { ether }\end{array}$ & 23.0 & 10.0 & 27.7 & 83.3 \\
\hline Henna extracted by ethyl alcohol & 22.7 & 9.7 & 27.3 & 76.7 \\
\hline New L.S.D. at 5\% & 4.17 & 5.55 & 2.87 & 8.01 \\
\hline
\end{tabular}

\section{Changes in bud endogenous hormones contents}

Taple (6) illustrates bud contents of endogenous absissic acid (ABA), gibberellins (GA) and indole acetic acid (IAA) expressed as $\mathrm{mg} / 100 \mathrm{~g}$ fresh weight (F.W.) in bud samples detached from Dogridge cuttings before treatments as well as one and two months after treatment and planting. Samples were taken from cuttings, in the second season only (2011). 


\section{a. Gibberellin (GA) content}

$\mathrm{GA}_{3}$ content was increased gradually with the advance in time after planting. Thus, untreated buds indicated $0.002 \mathrm{mg} \mathrm{GA} / 100 \mathrm{~g}$ F.W. before planting, while recorded 0.02 and $0.436 \mathrm{mg} \mathrm{GA} / 100 \mathrm{~g}$ F.W. at one and two months after planting, respectively. Henna extracts by different solvents and IBA treatments generally enhanced bud GA content, the values ranged from 0.020 to $0.740 \mathrm{mg} \mathrm{GA} / 100 \mathrm{~g} \mathrm{F.W}$. after one month and from 0.436 to $2.88 \mathrm{mg} \mathrm{GA} / 100 \mathrm{~g}$ F.W. after two months.

The highest values were obtained from henna extracted by acetone, hexane and tap water, solvents at one and two months after planting.

Henna extracted by acetone gave the highest GA values(1.160 \& $2.880 \mathrm{mg} \mathrm{GA} / 100 \mathrm{~g}$ F.W.) after one and two months from planting, while untreated cuttings gave GA content lowest values(0.020 \& $0.436 \mathrm{mg} \mathrm{GA} / 100 \mathrm{~g}$ F.W.) after one and two months respectively.

Taple 6. Effect of different henna extracts compared with IBA on bud endogenous hormones contents ( $\mathrm{mg} / \mathrm{100 \textrm {g }}$ fresh weight) of Dogridge grape rootstock cuttings at the second season only (2011).

\begin{tabular}{|c|c|c|c|}
\hline \multirow[t]{2}{*}{ Treatments } & \multicolumn{3}{|c|}{$\begin{array}{l}\text { Changes in bud endogenous hormones contents } \\
\qquad \mathrm{mg} / 100 \mathrm{~g} \mathrm{F.W.}\end{array}$} \\
\hline & (GA) content & ( IAA) content & (ABA) content \\
\hline $\begin{array}{l}\text { Endogenous hormones contents } \\
\text { (mg/100g F.W.) period before planting }\end{array}$ & 0.002 & 0.006 & 6.76 \\
\hline \multicolumn{4}{|c|}{ After one months from planting } \\
\hline Untreated cutting & 0.020 & 0.002 & 2.01 \\
\hline IBA (1000 ppm) & 0.150 & 0.009 & 1.27 \\
\hline Henna extracted by tap water & 0.740 & 0.033 & 0.24 \\
\hline Henna extracted by boiled water & 0.190 & 0.023 & 0.08 \\
\hline Henna extracted by acetone & 1.160 & 0.242 & 0.16 \\
\hline Henna extracted by hexane & 0.590 & 0.383 & 0.11 \\
\hline Henna extracted by petroleum ether & 0.720 & 0.020 & 0.03 \\
\hline Henna extracted by ethyl alcohol & 0.235 & 0.008 & 0.29 \\
\hline \multicolumn{4}{|c|}{ After two months from planting } \\
\hline Untreated cutting & 0.436 & 0.009 & 0.005 \\
\hline IBA (1000 ppm) & 1.010 & 0.010 & 0.000 \\
\hline Henna extracted by tap water & 1.400 & 0.426 & 0.000 \\
\hline Henna extracted by boiled water & 0.722 & 0.100 & 0.000 \\
\hline Henna extracted by acetone & 2.880 & 0.490 & 0.000 \\
\hline Henna extracted by hexane & 2.190 & 0.820 & 0.000 \\
\hline Henna extracted by petroleum ether & 1.281 & 0.050 & 0.000 \\
\hline Henna extracted by ethyl alcohol & 0.960 & 0.020 & 0.002 \\
\hline
\end{tabular}




\section{b. Indole acetic acid (IAA) content}

IAA content of untreated buds was at its lowermost level $(0.006 \mathrm{mg} / 100 \mathrm{~g}$ F.W.) before planting, and it increased gradually after planting.

Henna extracts and IBA treatment, generally enhanced IAA content of buds, the values ranged from ( 0.002 to $0.242 \mathrm{mg} / 100 \mathrm{~g}$ F.W.) after one month and ranged from ( 0.010 to $0.820 \mathrm{mg} / 100 \mathrm{~g}$ F.W.) after two months from planting.

The highest values were obtained from henna extracted by hexane and acetone followed by tap water, while the lowest values always obtained from untreated cuttings. The other treatments gave in between values.

\section{c. Absissic acid (ABA) content}

ABA content of buds was gradually decreased with the advance in time. Untreated buds recorded (6.76 mg / 100 g F.W.) before planting while recorded (2.01 \& $0.005 \mathrm{mg} / 100 \mathrm{~g} \mathrm{F.W}$. at one and two months after planting.

Henna extracts and IBA treatment generally depressed ABA content, the lowermost $A B A$ content was obtained from all henna extracts especially after two months from planting. The values ranged from (0.03 to $2.01 \mathrm{mg} / 100 \mathrm{~g}$ F.W.) after one months from planting. All henna extracts after two months gave 0.000 ABA content except henna extracted by ethyl alcohol recorded $(0.002 \mathrm{mg} / 100 \mathrm{~g}$ F.W. $)$ The effect of henna extract on bud ABA content was clear enough. Thus, all extracts depressed ABA content before development.

The obtained results are in general agreement with Gehan H. Sabry, (2004) who worked on Dogridge rootstock.

\section{Determination of total analysis of henna extracted by different solvents}

Taple(7) illustrates constituents of henna extracts, the results were obtained by henna extracted by acetone and tap water solvents without significant differences among them. The promotion of roots may be due to presence of some constituents as Tannins, Sterols\&/triterpenes and flavonoids. Its was clear that, henna extract by tap water contains Tannins. Henna extracts by acetone and petroleum ether solvents contain Sterols\&/triterpenes and flavonoids while henna extract by hexane solvent contain Sterols\&/triterpenes.

On the other hand, the weak rooting of henna extract by ethyle alcohol solvent may be due to presence of Cardiac glycosides.

Generally, it is possible to improve rootapility of Dogridge grape rootstock cuttings by soaking cuttings in henna extracted by acetone and tap water solvents which gave nearly similar effect, but use of tap water solvent weaks be more economic and easier for application. 
Taple 7. Determination of total analysis of henna extracted by different solvents.

\begin{tabular}{|c|c|c|c|c|c|c|}
\hline \multirow{2}{*}{ Constituents } & \multicolumn{5}{|c|}{ Henna extracted by different solvent } \\
\cline { 2 - 7 } & Hexane & $\begin{array}{c}\text { Petroleu } \\
\text { m ether }\end{array}$ & Acetone & $\begin{array}{c}\text { Ethyl } \\
\text { alcohol }\end{array}$ & $\begin{array}{c}\text { boiled } \\
\text { water }\end{array}$ & $\begin{array}{c}\text { Tap } \\
\text { water }\end{array}$ \\
\hline Tannins & - & - & - & - & + & + \\
\hline Saponins & - & - & - & - & + & - \\
\hline Sterols\&/triterpenes & + & + & + & + & & \\
\hline Alkaloids & - & - & - & - & - & - \\
\hline Cardiac glycosides & - & - & - & + & - & - \\
\hline Anthraquinones & - & - & - & - & - & - \\
\hline Flavonoids & - & + & + & + & - & - \\
\hline
\end{tabular}

This work will followed by a series of studies to moniter in details the active ingredients within each henna extract. Parallel trials with the synthetic chemical compounds appeared in the most effective henna extracts i.e. Tannins (tap water extract) and Sterols\&/triterpenes (acetone extract).

\section{REFERENCES}

1. Munday, R., E. A. Fowke, B. L. Smith and C. M. Munday. 1994. Comparative toxicity of alkyl-1,4-naphthoquinones in rats: Relationship to free radical production in vitro. Free Rad. Biol. Med. 16, 725-731.

2. Munday, R., B. L. Smith and E. A. Fowke. 1991. Haemolytic activity and nephrotoxicity of 2-hydroxy-1,4-naphthoquinone in rats. J. Appl. Toxicol. 11, 8590.

3. Raupp, P., J. A. Hassan, M. Varughese and B. Kristiansson. 2001. Henna causes life threatening haemolysis in glucose-6-phosphate dehydrogenase deficiency. Arch. Dis. Child. 85, 411-412.

4. Sabry, Gehan H. 2004. Studies on propagation of dogridge grape rootstock and it's tolerance to salinity and nematodes compared with european grapevines(PH.D Thsis) Faculty of Agriculture, Zagazig University. 
5. Sauer, M. R. 1977. Nematode resistant grape rootstocks. Am. J. Enol. Vitic. 31 (3): 250-353.

6. Shahidi, F. and M. Naczk. 1995. Methods of analysis and quantification of phenolic compounds. Food phenolic: sources, chemistry, effects and applications. Technomic Publishind Company, Inc: Lancaster, PA, 287-293.

7. Snedecor, G. W. and W.G. Cochran. 1980. Statistical Methods. 7th ed. Iowa state Univ., Press, Iowa, U. S. A.

8. Wasfy, W. S. 1975. Identification of plant hormones from cotton ovules. Plant Physiol. 55: 550-554.

9. Winkler, A. J., J. A. Cook, W. M. Kliewer and L. A. Lider. 1974. General Viticulture. University of Calif. Press. Berkely, Los Angles, London, 689-692.

10. Zinkham, W. H. and F. A. Oski. 1996. Henna: A potential cause of oxidative hemolysis and neonatal hyperbilirubinemia. Pediatrics 97, 707-709. 


\section{دراسات مبائية لاستخدام مستخلصات مختلفة من الحناء مقارنة بحض الاندول

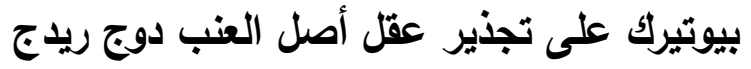

$$
\begin{aligned}
& \text { أيمن محمود أحمد حمودة } 1 \text { جيهان حسين صبرى محمود2 } \\
& \text { 1. قسم بحوث النباتات الطبية والعطرية - معهة بحوث البساتين - مركز البحوث الزراعية }
\end{aligned}
$$

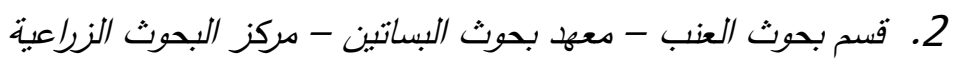

أجريت هذة الدراسة خلال موسمى 2010 \& 2011 فى الصوبة الخاصة بقسم بحوث العنب

$$
\text { - معهد بحوث البساتين بالجيزة- مركز البحوث الزراعية - وزارة الزراعة. }
$$

أخذت العقل من كروم دوج ريدج نامية فى مزرعة خاصة بالكيلو 58 طريق مصر الاسكندرية

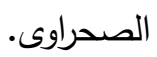

أخذت العقل الخشبية فى يناير من قصبات معتدلة النمو عمر سنة وإحتوت كل عقلة على ثلاث عيون وبطول 30 - 35 سم. تم تخزين العقل مقلوبة فى الصوبة حتى زراعتها فى 15 فبراير فى كلا

تم الحصول على مستخلصات الحناء من نقع 200 جم من الوراق الحناء الجافة المجروشة فى 1 لتر

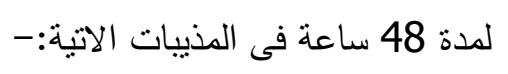

ماء صنبور , ماء مغلى , كحول الايثيل , هكسان , أسيتون , بتروليم ايثر.

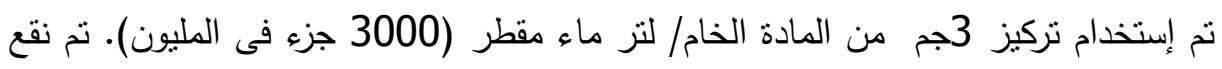

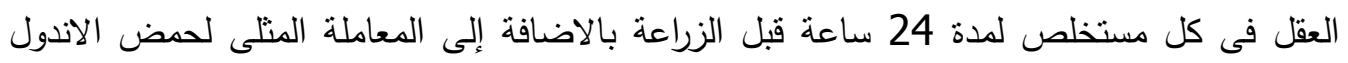
بيوترك (1000 جزء فى المليون) بغس قواعد العقل لمدة 10 ثوانى كمعاملة كنترول.

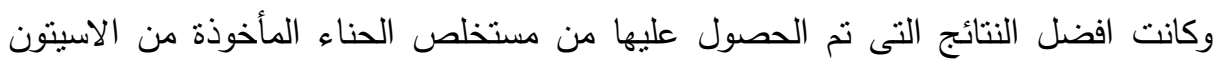

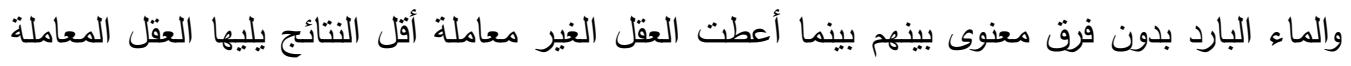
بمستخلص الحناء بكحول الايثيل ثم العقل المعاملة بحمض الاندول بيوتيرك بينما تراوحت نتائج باقى الثي مستخلصات الحناء فيما بينهما. عموما يمكن تحسين قابلية عقل أصل العنب دوج ريدج للنجذير بنقع قواعد العقل فى العياء

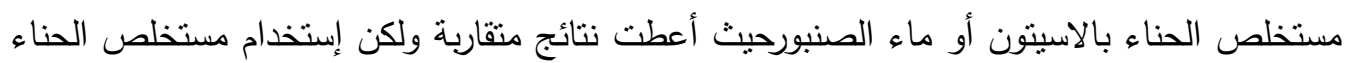
بماء الصنبور يعتبر أسهل تطبيقياً وأقل تكلفة إقتصادية. 